\title{
PANDANGAN TOKOH AGAMA DAN BUDAYA MASYARAKAT TERHADAP PEMAKAIAN ALAT KONTRASEPSI
}

\author{
Hartini \\ Jurusan Antropologi FISIP Unhalu \\ Email:hartini@yahoo.com
}

\begin{abstract}
Reproduction health care for husband and wife provides equal right in deciding the best medical practice related to reproduction's function and process. However, the reality shows the irony of the fact that using contraception's tool is mostly dominated by women. It is due to the strong perception of religious figures and social figures on the usage of contraception that is most suitable for women and it is considered as taboo for men to practice the sort of reproduction health care.

Pemeliharaan kesehatan reproduksi suami dan istri sebagai keluarga mempunyai hak yang sama untuk menentukan tindakan yang terbaik berkaitan dengan fungsi dan proses memfungsikan alat reproduksinya. Namun dalam kenyataannya kewajiban pemeliharaan kesehatan reproduksi khususnya dalam pemakaian alat kontrasepsi lebih banyak didominasi perempuan. Hal ini terjadi karena masih kuatnya pandangan tokoh agama dan tokoh masyarakat tentang pemakaian alat kontrasepsi yang dianggap hanya pantas dilakukan oleh perempuan dan masih dianggap tabu jika laki-laki menggunakan alat kontrasepsi.
\end{abstract}

Keywords : kesehatan reproduksi, agama, masyarakat, alat kontrasepsi

\section{Pendahuluan}

Dalam rangka pemeliharaan kesehatan reproduksi suami dan istri sebagai keluarga mempunyai hak untuk menentukan tindakan yang terbaik berkaitan dengan fungsi dan proses memfungsikan alat reproduksinya. Segala sesuatu yang mempengaruhi sikap dan perilaku dalam berbagai 
bentuk anjuran, meskipun dengan tujuan mulia, hak memutuskan tetap berada pada pasangan suami istri. Namun dalam kenyataannya kewajiban pemeliharaan kesehatan reproduksi khususnya dalam pemakaian alat kontrasepsi lebih banyak didominasi perempuan, walaupun dalam proses pemutusannyamelibatkan laki-laki,namunlaki-lakilebihcenderungbersifat pasif. Hal ini terjadi karena masih kuatnya pandangan tokoh masyarakat dan tokoh agama tentang pemakaian kontrasepsi laki-laki khususnya secara sosial budaya. Hal ini karena masyarakat masih menganggap tabu/ kurang mendukung jika laki-laki menggunakan alat kontrasepsi. Selain itu perilaku sebagian besar tokoh masyarakat dan suami yang belum bisa menerima KB bagi laki-laki terutama Vasektomi. Dengan menggunakan alasan bahwa agama tidak memperbolehkan. Hal yang serupa disampaikan oleh laki-laki bahwa bila laki-laki menggunakan alat kontrasepsi dianggap tidak perkasa lagi, selain itu dalam hubungan seksual dianggap tidak kuat dan bapak jika berselingkuh tidak ketahuan. Ada pula yang menganggap KB itu urusan ibu-ibu. Seperti yang dituturkan oleh sebagian ulama, bahwa kontrasepsi belum diprogramkan dan dianggap haram, kecuali bila terdesak misal anak sudah banyak dan tidak satu pun metode KB yang cocok

Tidak mudah bagi masyarakat untuk menerima laki-laki berpartisipasi aktif dalam program keluarga berencana (KB) karena berbagai alasan, salah satunya adalah hambatan budaya yang masih dominan terhadap tabunya pemakaian alat kontrasepsi pada laki-laki, khususnya kontrasepsi mantap. Hal ini didukung pendapat BKKBN (2007) bahwa kesertaan laki-laki untuk menggunakan alat kontrasepsi masih rendah. Hal ini terjadi karena faktor sosial budaya masyarakat yang beranggapan bahwa KB adalah urusan perempuan sehingga laki-laki tidak perlu berperan secara aktif dalam KB.

Hasil penelitian Kusumaningrum (2009) menyatakan bahwa adanya aksesibilitas laki-laki terhadap informasi mengenai $\mathrm{KB}$ yang rendah serta aksesibilitas laki-laki terhadap sarana pelayanan kontrasepsi rendah, mengakibatkan kesertaan laki-laki untuk menggunakan alat kontrasepsi sangat rendah. Rendahnya aksebilitas ini juga didukung oleh masih terfokusnya puskesmas pada pelayanan kesehatan untuk ibu dan anak saja, sehingga laki-laki merasa enggan untuk konsultasi dan mendapat pelayanan, demikian pula terbatasnya jumlah sarana pelayanan yang dapat 
memenuhi kebutuhan laki-laki serta waktu buka sarana pelayanan tersebut. Menurut New comb dalam Notoatmodjo (2003) selama ini laki-laki hanya menunjukkan sikap mendukung penggunaan alat kontasepsi pada wanita, belum menunjukkan kesiapan atau kesediaan untuk bertindak sebagai pengguna alat kontrasepsi tersebut.

Bertrand (1994) memaparkan bahwa diberbagai negara, faktor sosial ekonomi dan faktor budaya masih sangat menentukan norma ukuran keluarga. Karakteristik sosial-demografi dan psikososial dapat mempengaruhi keinginan ukuran keluarga pada tingkat individu. Pelayanan KB yang siap tersedia tidak hanya dapat memenuhi permintaan untuk mengatur jarak atau membatasi kelahiran, tetapi juga menciptakan suatu permintaan jasa dalam menyediakan pelayanan alternatif untuk meneruskan childbearing dan keberhasilan pencegahan kehamilan.

Dalam memperkenalkan cara-cara kontrasepsi kepada masyarakat khususnya laki-laki tidak mudah untuk segera menerima karena menyangkut pengambilan keputusan oleh masyarakat untuk menerima cara-cara kontrasepsi tersebut. ada empat tahap untuk mengambil keputusan menerima inovasi tersebut, yaitu tahap pengetahuan (knowledge), tahap persuasi (persuasion), tahap pengambilan keputusan (decision), dan tahap konfirmasi (confirmation). Melalui tahap-tahap tersebut, inovasi bisa diterima maupun ditolak.

Inovasi akan ditolak jika inovasi tersebut dipaksakan oleh pihak lain, inovasi tersebut tidak dipahami, atau inovasi tersebut dianggap sebagai ancaman terhadap nilai-nilai penduduk. Selanjutnya akan terjadi penerimaan secara selektif yaitu ada beberapa inovasi yang diterima / diterima sebagian sedangkan beberapa inovasi lainnya ditunda atau bahkan ditolak. Jadi penerimaan inovasi tidak pernah bersifat menyeluruh tetapi bersifat selektif dengan berbagai pertimbangan.

\section{Partisipasi Suami Istri Dalam KB}

Peran atau partisipasi suami istri dalam Keluarga Berencana (KB) antara lain menyangkut :

a. Pemakaian alat kontrasepsi

b. Tempat mendapatkan pelayanan

c. Lama pemakaian

d. Efek samping dari penggunaan kontrasepsi 
e.Siapa yang harus menggunakan kontrasepsi

Peran suami istri dalam hal berkomunikasi mengenai kontrasepsi antara lain :

a. Suami memakai kontrasepsi

b. Istri memakai kontrasepsi tapi tidak dibicarakan dengan suami

c. Suami istri tidak memakai kontrasepsi, tapi dibicarakan antara suami istri

d. Suami istri tidak memakai dan tidak dibicarakan antara suami istri.

Peningkatan partisipasi pria dalam KB dan kesehatan reproduksi adalah langkah yang tepat dalam upaya mendorong kesetaraan gender. Partisipasi pria dalam kesehatan reproduksi adalah tanggung jawab pria dalam kesehatan reproduksi, terutama dalam pemeliharaan kesehatan dan kelangsungan hidup ibu dan anak, serta berprilaku seksual yang sehat dan aman bagi dirinya, istri, dan keluarganya.

Dalam kurun waktu 30 tahun keberhasilan program KB masih banyak didominasi oleh peran serta wanita dalam penggunaan alat dan metode kontrasepsi. Pada tahun 2002 tercatat tingkat pemakaian kontrasepsi adalah $60,3 \%$. Kontribusi pria terhadap angka tersebut hanya $1,3 \%$ saja yang terdiri dari kondom $(0,9 \%)$ dan vasektomi $(0,4 \%)$. Ini berarti $59 \%$ pemakai kontrasepsi adalah wanita.

Ada banyak faktor yang menyebabkan rendahnya peserta KB pria antara lain:

a. Kondisi lingkungan sosial budaya, masyarakat dan keluarga yang masih menganggap partisipasi pria belum atau tidak penting dilakukan serta pandangan yang cenderung menyerahkan tanggung jawab pelaksanaan KB dan kesehatan reproduksi sepenuhnya kepada para wanita.

b. Pengetahuan, kesadaraan Pasangan Usia Subur (PUS) dan keluarga dalam KB pria rendah.

c. Keterbatasan jangkauan (aksesibilitas) dan kualitas pelayanan KB pria.

Meskipun dari dua metode KB pria telah tersedia berbagai merek kondom dan telah dikembangkan beberapa teknik 
vasektomi yang relatif lebih baik, namun seringkali menjadi alasan utama yang dikemukakan dari berbagai pihak mengapa kesertaan pria dalam $\mathrm{KB}$ rendah adalah terbatasnya metode atau cara kontrasepsi yang tersedia.

d. Dukungan politis dan operasional masih rendah di semua tingkatan.

Hal tersebut di atas membahas tentang partisipasi pria secara langsung dalam ber-KB (sebagai peserta $\mathrm{KB}$ pria dengan menggunakan salah satu cara atau metode pencegahan kehamilan), namun ada pula partisipasi pria secara tidak langsung dalam ber-KB. Partispasi pria secara tidak langsung salah satunya dengan cara mendukung istri dalam ber-KB. Apabila disepakati istri yang akan ber-KB, peranan suami adalah memberikan dukungan dan kebebasan kepada istri untuk menggunakan kontrasepsi atau cara/metode KB, adapun dukungannya meliputi :

- Memilih kontrasepsi yang cocok, yaitu kontrasepsi yang sesuai dengan keinginan dan kondisi istrinya.

- Membantu istrinya dalam menggunakan kontrasepsi secara benar, seperti mengingatkan saat minum pil KB dan mengingatkan istri untuk kontrol.

- Membantu mencari pertolongan bila terjadi efek samping maupun komplikasi dari pemakaian alat kontraspsi.

- Mengantar istri ke fasilitas pelayanan kesehatan untuk kontrol atau rujukan.

- Mencari alternatif lain bila kontrasepsi yang digunakan saat ini terbukti tidak memuaskan.

- Membantumenghitungwaktu subur, apabilamenggunakan metode pantang berkala.

- Menggunakan kontrasepsi bila keadaan kesehatan istri tidak memungkinkan

Selain faktor-faktor tersebut masih banyak faktor lain yang mempengaruhi pemilihan jenis kontrasepsi seperti tingkat pendidikan, pengetahuan, kesejahteraan keluarga, agama, dan dukungan dari suami/ istri. Faktor-faktor ini nantinya juga akan mempengaruhi keberhasilan 
program KB. Hal ini dikarenakan setiap metode atau alat kontrasepsi yang dipilih memiliki efektivitas yang berbeda-beda. Dalam rangka pemeliharaan kesehatan reproduksi suami dan istri sebagai keluarga mempunyai hak untuk menentukan tindakan yang terbaik berkaitan dengan fungsi dan proses memfungsikan alat reproduksinya. Segala sesuatu yang mempengaruhi sikap dan perilaku dalam berbagai bentuk anjuran, meskipun dengan tujuan mulia, hak memutuskan tetap berada pada pasangan suami istri.

\section{Pandangan Agama Terhadap Pemakaian Alat Kontasepsi}

KB bukan hanya masalah demografi dan klinis tetapi juga mempunyai dimensi sosial-budaya dan agama, khususnya perubahan sistim nilai dan norma masyarakat, seperti yang diatur dalam UU No.10 tahun 1992, tentang Pembangunan Kependudukan dan Keluarga Sejahtera. Dalam undang-undang tersebut juga telah dinyatakan bahwa penyelenggaraan pengaturan kelahiran, dilakukan dengan cara yang dapat dipertanggungjawabkan dari segi kesehatan, etik dan agama yang dianut penduduk yang bersangkutan (Pasal 17 ayat 2).

KB perlu mendapat dukungan masyarakat, termasuk tokoh agama, walaupun awalnya mendapat tantangan akhirnya program $\mathrm{KB}$ didukung tokoh agama dengan pemahaman bahwa KB tidak bertentangan dengan agama dan merupakan salah satu upaya dalam pengaturan masalah kependudukan untuk memerangi kemiskinan, kebodohan, keterbelakangan dan ketidakpedulian masyarakat, sehingga dapat mendukung pembangunan bangsa. Di pihak lain, peserta KB yan lebih dari 22,5 juta banyaknya juga memerlukan pegangan, pengayoman dan dukungan rohani yang kuat dan ini hanya bisa diperoleh dari pemimpin agama.

Program KB juga telah memperoleh dukungan dari Departemen Agama Republik Indonesia. Hal ini terlihat dengan penandatanganan bersama Badan Koordinasi Keluarga Berencana Nasional (BKKBN), Memorandum of Understanding (MoU) Nomor 1 Tahun 2007 dan Nomor: 36/HK.101/F1/2007 tentang Advokasi, Komunikasi, Informas dan Edukasi Program KB Nasional melalui Peran Lembaga Keagamaan, pada 9 Februari 2007, yang berlaku sampai dengan 31 Desember 2009.

Dalam Islam masih terdapat kontroversi mengenai KB, dimana ada yang memperbolehkan dan sebaliknya. Alasan yang dikemukakan adalah Al Qur'an tidak membolehkan pemakaian alat kontrasepsi yang dianggap 
sebagai membunuh bayi, atau agama Islam menginginkan agar Islam mempunyai umat yang besar dan kuat. Para ulama yang memperbolehkan KB sepakat bahwa KB yang dibolehkan syariat adalah usaha pengaturan atau penjarangan kelahiran atau usaha pencegahan kehamilan sementara atas kesepakatan suami-istri karena situasi dan kondisi tertentu untuk kepentingan (maslahat) keluarga. Jadi jelas bahwa Islam membolehkan KB karena penting untuk menjaga kesehatan ibu dan anak, menunjang program pembangunan kependudukan lainnya dan menjadi bagian dari hak asazi manusia. Agama selain Islam di Indonesia umumnya mendukung KB. Agama Hindu memandang bahwa setiap kelahiran harus membawa manfaat, maka kelahiran harus diatur jaraknya dengan ber KB. Agama Buddha, yang memandang setiap manusia pada dasarnya baik, tidak melarang umatnya ber-KB demi kesejahteraan keluarga. Agama Kristen Protestan tidak melarang umatnya ber-KB, yang mana sedikit berbeda dengan agama Katolik yang memandang kesejahteraan keluarga diletakkan dan diwujudkan dalam pemahaman holistik sesuai dengan kehendak Allah. Untuk mengatur kelahiran anak, suami-istri harus tetap menghormati dan menaati moral Katolik. Gereja Katolik hanya menerima abstinensia dan pantang berkala (hubungan seksual hanya dilakukan pada masa tidak subur dalam siklus bulanan seorang wanita) sebagai metode keluarga berencana yang sesuai dengan pandangan gereja dan menolak secara tegas metode KB lainnya.

\section{Partisipasi Pemakaian Alat Kontrasepsi pada Laki-laki}

Dreman and Robey (1998) menyatakan bahwa pendidikan menunjukkan pengaruh yang lebih kuat terhadap fertilitas daripada variabel lain. Pendidikan merupakan salah satu faktor yang sangat menentukan pengetahuan dan persepsi seseorang terhadap pentingnya sesuatu hal, termasuk pentingnya keikutsertaan dalam KB. Ini disebabkan seseorang yang berpendidikan tinggi akan lebih luas pandangannya dan lebih mudah menerima ide dan tata cara kehidupan baru (BKKBN, 1980).

Hubungan antara pendidikan dengan pola pikir, persepsi dan perilaku masyarakat memang sangat signifikan, dalam arti bahwa semakin tinggi tingkat pendidikan seseorang semakin rasional dalam pengambilan berbagai keputusan. Peningkatan tingkat pendidikan akan menghasilkan tingkat kelahiran yang rendah karena pendidikan akan mempengaruhi 
persepsi negatif terhadap nilai anak dan akan menekan adanya keluarga besar. Orang tua dalam keluarga tentu saja menginginkan agar anaknya berkualitas dengan harapan dikemudian hari dapat melanjutkan cita-cita keluarga, berguna bagi masyarakat dan negara. Untuk sampai pada cita-cita tersebut tentu saja tidak mudah, dibutuhkan strategi dan metode yang baik. Apakah mungkin menciptakan anak yang berkualitas di tengah waktu yang terbatas, karena kesibukan bekerja, dan apakah mungkin menciptakan anak berkualitas di tengah kondisi keuangan atau pendapatan yang terbatas.

Dalam hubungan dengan pemakaian kontrasepsi, pendidikan akseptor dapat mempengaruhi dalam hal pemilihan jenis kontrasepsi yang secara tidak langsung akan mempengaruhi kelangsungan pemakaiannya.

Penelitian menunjukkan bahwa tingkat pendidikan yang dimiliki mempunyai pengaruh yang kuat pada perilaku reproduksi dan penggunaan alat kontrasepsi. Berdasarkan SDKI 2002-2003, pemakaian alat kontrasepsi meningkat sejalan dengan tingkat pendidikan. Sebesar 45\% wanita yang tidak sekolah menggunakan cara kontrasepsi modern, sedangkan wanita berpendidikan menengah atau lebih tinggi yang menggunakan cara kontrasepsi modern sebanyak 58\%. Jadi, secara umum semakin tinggi tingkat pendidikan wanita, semakin besar kemungkinannya memakai alat/ cara $\mathrm{KB}$ modern.

Menurut BKKBN (2005) upaya peningkatan partisipasi lakilaki terkendala oleh beberapa ketentuan peraturan daerah yang belum mengakomodir jenis kontrasepsi mantap laki-laki, seperti halnya aspek biaya yang harus ditanggung peserta terlalu tinggi, karena masuk rumpun tindakan operasi di rumah sakit umum daerah (RSUD). Di lain pihak biaya bantuan yang tersedia dari BKKBN jumlahnya terbatas dan tidak mampu menutupi biaya yang ditetapkan daerah. Penggunaan dana Asuransi keluarga miskin (ASKES GAKIN) belum lancar sebagaimana diharapkan. Kesepakatan antara pihak asuransi dengan pihak BKKBN sebagai penyedia data dan distribusi Kartu Askes masih mewarnai permasalahan di lapangan.

Pelayanan Kontrasepsi mantap juga terkendala oleh ketersediaan dan kesiapan tenaga pelayanan. Dukungan sarana pelayanan juga menjadi kendala di beberapa daerah, tenaga terlatih sudah banyak yang alih tugas dan peralatan kurang lengkap. Terbatasnya akses pelayanan 
KB laki-laki dan kualitas pelayanan KB laki-laki belum memadai juga merupakan aspek yang mempengaruhi rendahnya partisipasi laki-laki dalam Keluarga Berencana. Selain itu menurut BKKBN (2007) faktorfaktor yang mempengaruhi rendahnya partisipasi laki-laki dalam KB, antara lain terbatasnya sosialisasi dan promosi KB laki-laki, adanya persepsi bahwa wanita yang menjadi target program KB, terbatasnya akses pelayanan KB laki-laki, tingginya harga yang harus dibayar untuk ber KB, ketidaknyamanan dalam penggunaan KB laki-laki (kondom), terbatasnya metode kontrasepsi laki-laki, rendahnya pengetahuan lakilaki terhadap KB, kualitas pelayanan KB laki-laki belum memadai, istri tidak mendukung suami ber-KB, adanya stigmatisasi tentang KB lakilaki di masyarakat, kondisi politik, sosial budaya masyarakat, agama, dan komitmen pemerintah masih belum optimal dalam mendukung KB lakilaki dimana penerapan program kebijakan partisipasi laki-laki di lapangan masih belum optimal.

Berdasarkan hasil penelitian kualitatif yang dilakukan Wijayanti (2004) secara sosial budaya menunjukkan hasil bahwa semua responden menyatakan metode $\mathrm{KB}$ bagi laki-laki belum membudaya atau belum umum dilakukan oleh masyarakat di desa Timpik Kecamatan Susukan Kabupaten Semarang. Kondisi sosial budaya masyarakat yang patrilinial yang memungkinkan kaum perempuan berada dalam sub ordinasi menyebabkan pengambilan keputusan dalam KB didominasi oleh kaum laki-laki.

Menurut Bertrand (2007) budaya dominasi laki -laki (budaya patriarkhi) didasari oleh kekuatan dan kekuasaan materi. Menyimak hasil penelitian BKKBN (1998) tentang faktor sosial, ekonomi dan budaya menerangkan bahwa nilai budaya, seperti pandangan terhadap banyak anak adalah banyak rejeki, preferensi jenis kelamin anak, dan pandangan agama yang dianut secara inferensial tidak menunjukkan pengaruh yang signifikan.

Di daerah pedesaan anak mempunyainilai yang tinggi bagi keluarga. Anak dapat memberikan kebahagiaan kepada orang tuanya selain itu akan merupakan jaminan di hari tua dan dapat membantu ekonomi keluarga, banyak masyarakat di desa di Indonesia yang berpandanga bahwa banyak anak banyak rejeki, selain itu pandangan mayoritas budaya masyarakat di 
dunia ini menunjukkan kecenderungan untuk lebih menyenangi kelahiran anak laki-laki, dibandingkan kelahiran anak perempuan. Preferensi jenis kelamin laki-laki terutama terjadi di kalangan budaya orang-orang Islam, Cina, India, dan di Indonesia, budaya ini ditemukan di masyarakat Batak, dan Bali. Preferensi anak laki-laki, nampaknya menjadi hambatan untuk mewujudkan cita-cita dua anak harus dianggap ideal dan juga untuk mengurangi tingkat fertilitas di China modern. Adat kebiasaan atau adat dari suatu masyarakat yang memberikan nilai anak laki-laki lebih dari anak perempuan atau sebaliknya. Hal ini akan memungkinkan satu keluarga mempunyai anak banyak. Keinginan untuk mendapatkan anak lakilaki atau perempuan tidak terpenuhi kemungkinan dapat menyebabkan suami akan menceraikan istrinya dan kawin lagi agar terpenuhi keinginan memiliki anak laki-laki ataupun anak perempuan. Disinilah norma adat istiadat perlu diluruskan karena tidak banyak menguntungkan bahkan banyak bertentangan dengan kemanusiaan. Bagi para pemeluk agama merencanakan jumlah anak adalah menyalahi kehendak Tuhan. Kita boleh mendahului kehendak Tuhan apalagi mencegah kelahiran anak dengan anak dengan menggunakan alat kontrasepsi supaya tidak hamil. Langkah utama untuk mengatasi hal ini adalah menemui tokoh-tokoh atau ulama dari agama tersebut untuk menjelaskan bahwa merencanakan keluarga untuk membantu Keluarga kecil adalah tidak bertentangan dengan agama.

Faktor yang mempengaruhi partisipasi laki-laki dalam Keluarga Berencana dapat menggunakan pendekatan faktor perilaku. Sedangkan faktor-faktor yang mempengaruhi perilaku ada 3 faktor utama, yaitu : faktor predisposisi (predisposing factors), faktor pemungkin (enabling factors), dan faktor penguat (reinforcing factors). Faktor predisposisi merupakan faktor anteseden terhadap perilaku yang menjadi dasar atau motivasi bagi perilaku. Yang termasuk kendala faktor ini adalah pengetahuan, sikap, keyakinan, nilai, adat istiadat (budaya) dan persepsi, berkenaan dengan motivasi seseorang atau kelompok untuk bertindak. Faktor predisposisi sebagai preferensi pribadi yang dibawa seseorang atau kelompok ke dalam suatu pengalaman belajar. Preferensi ini mungkin mendukung atau menghambat perilaku sehat, dalam setiap kasus, faktor ini mempunyai pengaruh. Berbagai faktor demografis seperti status sosial ekonomi, umur, jenis kelamin, dan ukuran keluarga penting sebagai faktor 
demografis. Faktor pemungkin adalah faktor antesenden terhadap perilaku yang memungkinkan suatu motivasi atau aspirasi terlaksana. Termasuk di dalam faktor pemungkin adalah keterampilan dan sumber daya pribadi atau komuniti. Seperti tersedianya pelayanan kesehatan, keterjangkauan, kebijakan, peraturan perundangan. Faktor penguat merupakan faktor penyerta (yang datang sesudah) perilaku yang memberikan ganjaran, insentif, atau hukuman atas perilaku dan berperan bagi menetap atau lenyapnya perilaku itu, yang termasuk ke dalam faktor ini adalah faktor sikap dan perilaku tokoh masyarakat, tokoh agama, sikap dan perilaku para petugas termasuk petugas kesehatan. Faktor penguat adalah faktor yang menentukan apakah tindakan kesehatan memperoleh dukungan atau tidak. Sumber penguat tentu saja tergantung pada tujuan dan jenis program. Di dalam pendidikan pasien, penguat mungkin berasal dari perawat, dokter, pasien lain, dan keluarga. Apakah penguat ini positif ataukah negatif bergantung pada sikap dan perilaku orang lain yang berkaitan, yang sebagian diantaranya lebih kuat daripada yang lain dalam mempengaruhi perilaku

Partisipasi laki-laki dalam kesehatan reproduksi adalah tanggung jawab laki-laki dalam kesehatan reproduksi terutama dalam pemeliharaan kesehatan dan kelangsungan hidup ibu dan anak, serta berprilaku seksual yang sehat dan aman bagi dirinya, istri, dan keluarganya. Peningkatan partisipasi laki-laki dalam KB dan kesehatan reproduksi adalah langkah yang tepat dalam upaya mendorong kesetaraan gender.

\section{Kesimpulan}

Ditinjau dari sudut keadaan agama dan sosial budaya masyarakat yang menganggap bahwa partisipasi laki-laki dalam ber KB belum atau tidak penting dilakukan, hal ini terjadi karena muunculnya pandangan yang cenderung menyerahkan tanggung jawab pelaksanaan KB dan kesehatan reproduksi sepenuhnya kepada para wanita. Selain itu laki-laki juga beranggapan bahwa KB adalah urusan perempuan sehingga pria tidak perlu berperan secara aktif.

\section{DAFTAR PUSTAKA}

BKKBN. 2000. Pedoman Penggarapan Peningkatan Partisipasi Pria. BKKBN. Jakarta 
BKKBN. 2001. Fakta, Data dan Informasi Kesenjangan Gender di Indonesia. BKKBN. Jakarta.

BKKBN. 2005. Peningkatan Akses dan Kualitas Pelayanan KB. BKKBN. Bandung.

BKKBN. 2007. Gender dalam Program KB dan KR. http://gemapria. bkkbn.go.id/artikel02-21.html

Bertrand. 2007. Kerangka Pikir Konseptual Permintaan KB serta Dampak Pada Fertilitas. Dalam : BKKBN. Peningkatan Akses dan Kualitas Pelayanan KB. BKKBN. Bandung.

Dreman and Robey. 1998. Male Participation in Reproductive Health. Network. Spring. 18(3) : 11-5.

Dwijayanti, Riski. 2006. Analisis Respon Masyarakat Desa terhadap Program KB dalam Rangka Peningkatan Kualitas Sumber Daya Manusia di desa Cihideung Udik kabupaten Bogor. http://dikti. go.id/pkm/pkmi-award/pdf/pkmi06-016.pdf.

Ekarini, S.M. 2008. Analisis Faktor-Faktor yang berpengaruh Terhadap Partisipasi Pria dalam KB di Kecamatan Selo Kabupaten Boyolali. Tesis S2, Universitas Diponegoro. Tidak Dipublikasikan.

Kusumaningrum, R. 2009. Faktor-faktor yang Mempengaruhi Pemilihan Jenis Kntrasepsi yang Digunakan Pada Pasangan Usia Subur. Universitas Diponegoro, Semarang. Tugas Akhir S1. Tidak dipublikasikan

Notoatmodjo, S. 2002. Metodologi Penelitian Kesehatan. Rineka Cipta. Jakarta.

Suprihastuti, dkk. 2000. Analisis Data Sekunder SDKI 97 Pengambilan Keputusan Penggunaan Alkon Pria di Indonesia. D.I. Yogyakarta.

Undang-Undang Nomor 10 tentang Pembangunan Kependudukan dan Keluarga Sejahtera. 1992

Wijayanti, Titik. 2004. Studi Kualitatif Alasan Akseptor Laki-Laki tidak 
154 Egalita Jurnal Kesetaraan dan Keadilan Gender, Volume VI No. 2 Juni 2011, hlm. 142-154

Memilih MOP sebagai Kontrasepsi Pilihan di desa Timpik kecamatan Susukan kabupaten Semarang. Program Studi Diploma IV Kebidanan Stikes Ngudi Waluyo. Ungaran. 